Muhammad Walid-Ketera mpilan Mana jerial Kepala Madrasah

\title{
KETERAMPILAN MANAJERIAL KEPALA MADRASAH/SEKOLAH DALAM MENINGKATKAN MUTU LULUSAN
}

\section{Muhammad Walid}

Dosen pada program studi PGMI dan PAI UIN Malang

\begin{abstract}
Managerial skill is an ability to perform a job base on a competence in which is done by objective and in collaboration with others. In education, leader's skill of school as manager is an ability of school leader to do a tasks base on the ability competence in leading the objective through $t$ he others. Whereas, the school leader who has the competence is getting of best of a work qualification that is agree with a work and in reality. The school leader who has a competence be able to do in his job effectively and efficiently. There are tree managerial skills those should be dominated by school leader: conceptual skill, technical skill, and skill for dealing with others.
\end{abstract}

Keyword: Manajerial Skill, Madrasah, Quality.

\section{A. Pendahuluan}

Untuk mampu dan tetap eksis berperan dalam perubahan tersebut di tengah-tengah berkembang pesatnya ilmu pengetahuan dan teknologi yang berdampak pada perubahan di semua sektor kehidupan manusia, kita perlu secara terus menerus mengembangkan dan meningkatkan kualitas sumber daya manusia. Peningkatan kualitas sumber daya manusia merupakan kenyataan yang harus dilakukan secara terarah, intensif, efektif dan efisien dalam proses pembangunan agar bangsa ini dapat bersaing di era globalisasi. Untuk meningkatan kualitas sumber daya manusia, peran pendidikan menjadi sangat penting. Kenyataan menunjukkan bahwa pendidikan di Indonesia secara kuantitatif berkembang pesat, namun sayangnya perkembangan pendidikan tersebut tidak diiringi dengan peningkatan kualitas pendidikan yang sejajar.

Menurut Dirjen Dikdasmen Depdiknas (2002) rendahnya kualitas pendidikan di Indonesia dapat disebabkan oleh beberapa faktor, di mana ada tiga faktor yang menyebabkan mutu pendidikan tidak mengalami peningkatan secara merata. Pertama, kebijakan dan penyelenggaraan pendidikan Nasional menggunakan pendekatan education product-function atau input - output analysis yang tidak di laksanakan secara konsekuen. Pendekatan ini melihat bahwa lembaga pendidikan berfungsi sebagai pusat produksi yang apabila akan dipenuhi semua input yang diperlukan dalam kegiatan produksi tersebut, maka lembaga akan menghasilkan output yang dikehendaki. 
Pendekatan ini menganggap bahwa apabila input pendidikan seperti pelatihan guru, pengadaan buku dan alat pelajaran, perbaikan sarana pendidikan lainnya dipenuhi, maka kualitas pendidikan (output) secara otomatis akan terjadi. Namun kenyataan sebaliknya, tidak terjadi peningkatan kualitas. Hal ini disebabkan karena dalam menerapkan pendekatan education-production-fuction terlalu memusatkan pada input pendidikan dan kurang memperhatikan pada proses pendidikan, padahal proses pendidikan sangat menentukan output pendidikan.

Faktor kedua, penyelenggaraan pendidikan Nasional dilakukan secara birokratik- sentralislik, sehingga menempatkan sekolah sebagai penyelenggaraan pendidikan sangat tergantung pada keputusan birokrasi yang mempunyai jalur yang sangat panjang dan kadang kebijakan yang dikeluarkan tidak sesuai dengan kondisi sekolah setempat, sekolah lebih merupakan subordinasi dan birokrasi di atasnya, sehingga sekolah kehilangan kemandirian, keluwesan, motivasi, kreatifitas dan inisiatif untuk mengembangkan dan menunjukkan lembaga pendidikannya, termasuk peningkatan kualitas pendidikan sebagai salah satu tujuan pendidikan Nasional.

Faktor ketiga, peran serta warga sekolah khususnya guru, peran serta masyarakat khususnya orang tua siswa dalam penyelenggaraan pendidikan selama ini sangat kurang. Partisipasi guru dalam pengambilan keputusan sering diabaikan padahal terjadi atau tidaknya perubahan di sekolah sangat tergantung pada guru. Dikenalkan pembaharuan apapun bila guru tidak berubah, maka tidak akan terjadi perubahan di sekolah tersebut. Partisipasi masyarakat selama ini pada umumnya sebatas pada dukungan dana, sedangkan dukungan lain seperti pemikiran, moral dan barang atau jasa kurang diperhatikan. Akuntabilitas sekolah terhadap masyarakat juga lemah. Sekolah tidak mempunyai beban untuk mempertanggungjawabkan hasil pelaksanaan pendidikan kepada masyarakat, khususnya orang tua siswa sebagai salah satu unsur utama yang berkepentingan dengan pendidikan (stakeholders).

Di samping ketiga faktor di atas, bila dikaji lebih mendalam tentang rendahnya kualitas pendidikan di Indonesia dapat dilihat dari sistem manajemen yang dipergunakan di sekolah, baik menyangkut kegiatan pembelajaran, manajemen sekolah maupun partisipasi masyarakat. Karena sistem terlalu sentralistik dalam manajemen pendidikan, maka banyak hal yang menjadi masalah, seperti rendahnya aktivitas pembelajaran, kurang terbukanya kepala sekolah dalam mengelola sekolah dan rendahnya partisipasi masyarakat terhadap kemajuan sekolah. Hal ini merupakan dampak dan terlalu kuatnya pihak pusat dalam mengatur sekolah.

Berdasarkan kenyataan di atas, maka muncul model pendekatan yang digunakan dalam mengelola organisasi sekolah, di mana sekolah diberi kewenangan (otonomi) yang lebih besar untuk mengatur sekolahnya 
dengan melibatkan segenap warga sekolah untuk mengambil keputusan secara partisipatif. Hal ini sejalan dengan lahirnya Undang-Undang Nomor 22 Tahun 1999 tentang otonomi daerah yang berimbang pada desentralisasi dan otonomi pendidikan.

Otonomi bertujuan untuk memandirikan dan memberdayakan sekolah melalui pemberian kewenangan (otonomi) kepada sekolah, pemberian fleksibilitas yang lebih besar kepada sekolah untuk mengelola sumber daya sekolah dan mendorong partisipasi warga sekolah dan masyarakat untuk meningkatkan mutu pendidikan dalam konteks pendidikan, pengertian mutu mencakup input proses dan output pendidikan.

Input pendidikan adalah segala sesuatu yang harus tersedia karena dibutuhkan untuk berlangsungnya proses pendidikan sesuatu yang dimaksud berupa sumber daya dan perangkat lunak serta harapanharapan sebagai pemandu bagi berlangsungnya proses pendidikan input sumber daya meliputi sumber daya manusia (kepala sekolah, guru, karyawan dan siswa) dan sumber daya selebihnya (media, perlengkapan, uang, bahan dan sebagainya). Input perangkat lunak meliputi struktur organisasi sekolah, peraturan perundang-undangan. deskripsi tugas, program dan sebagainya. Input harapan- harapan berupa visi, misi, tujuan dan sasaran-sasaran yang ingin dicapai oleh sekolah. Kesiapan input sangat diperlukan agar proses dapat berlangsung dengan baik. Oleh karena itu, tinggi rendahnya input dapat diukur dan tingkat kesiapan input. Makin tinggi tingkat kesiapan input, makin tinggi pula mutu input tersebut.

Proses pendidikan merupakan berubahnya sesuatu menjadi sesuatu yang lain. Sesuatu yang berpengaruh terhadap berlangsungnya proses disebut input, sedang sesuatu dan hasil proses disebut output. Dalam pendidikan berskala mikro (tingkat sekolah), proses yang dimaksud adalah proses pengambilan keputusan, proses pengelolaan kelembagaan, proses pengelolaan program, proses pembelajaran dan proses monitoring serta evaluasi, dengan catatan bahwa proses pembelajaran memiliki tingkat kepentingan tertinggi dibandingkan dengan proses-proses lainnya. Proses dikatakan bermutu tinggi a pabila pengkoordinasian dan penyerasian serta pemaduan input sekolah (guru, siswa, kurikulum, uang, media dan sebagainya) dilakukan secara harmonis, sehingga mampu menciptakan situasi pembelajaran yang menyenangkan, mampu mendorong motivasi dan minat belajar serta benar-benar mampu memberdayakan peserta didik.

Output pendidikan adalah merupakan kinerja sekolah. Kinerja sekolah adalah prestasi sekolah yang dihasilkan dan proses atau perilaku sekolah. Kinerja sekolah dapat diukur dan kualitasnya, efektivitasnya, produktivitasnya, efisiensinya, inovasinya. kualitas kehidupan kerjanya dan moral kerjanya. Khusus yang berkaitan dengan mutu output sekolah, 
dapat dijelaskan bahwa output sekolah dapat dikatakan berkualitas atau bermutu tinggi bila prestasi sekolah khususnya prestasi belajar siswa menunjukkan pencapaian yang tinggi dalam prestasi akademik dan prestasi non akademik. Mutu sekolah dapat dipengaruhi oleh banyak tahapan kegiatan yang saling berhubungan (proses) seperti perencanaan, pelaksanaan dan pengawasan.

Untuk mewujudkan hal tersebut di atas diperlukan seorang kepala sekolah yang mempunyai keterampilan manajerial yang mantap, sebagai kemampuan untuk dapat mengantisipasi semua kegiatan yang diperlukan. Dalam hal ini kepala sekolah memiliki peran yang kuat dalam mengkoordinasikan, menggerakkan dan menyerasikan semua sumberdaya pendidikan yang tersedia yang dimiliki oleh sekolah. Kepemimpinan kepala sekolah merupakan salah satu faktor yang dapat mendorong sekolah untuk dapat mewujudkan visi, misi, tujuan dan sasaran sekolahnya melalui program-program yang dilaksanakan secara terencana dan bertahap. Oleh karena itu, kepala sekolah dituntut memiliki kemampuan manajerial agar mampu mengambil keputusan, inisiatif (prakarsa) untuk meningkatkan mutu sekolah.

\section{B. Keterampilan Manajerial.}

Menurut Kast (1990) bahwa keterampilan adalah kompetensi yang berhubungan dengan pekerjaan. Sedangkan menurut Ndraha (1989) keterampilan adalah kemampuan melaksanakan tugas. Sedangkan menurut Dengan demikian dapat disimpulkan bahwa keterampilan adalah kemampuan dalam melaksanakan tugas berdasarkan kompetensi pekerjaan. Manajerial artinya yang berhubungan dengan manajer. Keterampilan manajerial dapat diartikan kemampuan untuk melaksanakan tugas berdasarkan kompetensi yang dilakukan oleh seorang manajer dalam mencapai tujuan, bekerjasama dengan orang lain.

Manajer dalam dunia pendidikan adalah kepala sekolah. Untuk dapat mencapai tujuan organisasi atau lembaga pendidikan, seorang manajer (kepala sekolah) dituntut memiliki keterampilan manajerial agar dapat menjalankan fungsi-fungsi manajemen yang diperlukan. Menurut Kast (1990) keterampilan manajerial tersebut diantaranya keterampilan konseptual, keterampilan hubungan dengan manusia dan keterampilan teknik.

Sebagai seorang pemimpin yang professional, seseorang bukan hanya mempunyai gaya dan menghayati nilai-nilai yang diperlukan di dalam masyarakat tetapi juga menguasai prinsip-prinsip manajemen modern. Di dalam kaitan ini, seorang pemimpin professional haruslah menguasai visi, misi dan program-program yang telah disepakati tetapi juga stratrgi yang sesuai dengan potensi masyarakat untuk melaksanakan program-program tersebut. Kemampuan manajerial tersebut meminta 
penguasaan akan sejumlah ilmu pengetahuan manajemen khususnya manajemen pendidikan. Selain itu suatu strategi yang mantap hanya dapat dilaksanakan di dalam suatu organisasi yang efisien. Oleh sebab itu, seorang pemimpin yang professional harus menguasai dan mengembangkan struktur organisasi pendidikan yang efisien, sehingga sumber daya yang tersedia baik sumber daya manusia maupun sumber dana serta instruktur lainnya dapat dimanfaatkan seoptimal mungkin, sehingga para pelaksana di dalam organisasi baik pada tingkat mikro yaitu sekolah, maupun pada tingkat masyarakat local dapat memanfaatkan berbagai sumber daya yang tersedia sebaik-baiknya untuk meningkatkan mutu pendidikan (Tilaar, 2004).

Kedua unsur profil manajer pendidikan merupakan satu kesatuan yang saling mengisi kepemimpinan yang professional, bukan hanya diperoleh dari penguasaan ilmu pengetahuan manajemen, tetapi juga di dalam pelaksanaan kepemimpinan itu sendiri. Dengan demikian kepemimpinan tersebut akan bersifat dinamis karena terus menerus diperkaya dari pengalaman-pengalaman di lapangan. Dari kepemimpinan yang dinamis akan menghasilkan prestasi dan kinerja yang semakin lama semakin meningkat dan terus menerus dievaluasi sehingga terjadi peningkatan kualitas yang berkesinambungan.

Peningkatan kualitas kepemimpinan pendidikan meliputi pengetahuan mengenai konsep-konsep kepemimpinan (conceptual skills), keterampilan kemanusiaan (human skills) yang meliputi pengetahuan mengenai kerjasama (teamwork), hubungan intermanusia yang menuntut inteligensi interpersonal, kemampuan administrasi dan evaluasi tingkah laku. Keterangan teknis (technical skills) meliputi antara lain pengetahuan mengenai gaya-gaya kepemimpinan yang sesuai untuk meningkatkan inisiatif dan inovasi dari para petugas dan pengelola pendidikan, serta kepemimpinan yang menghidupkan partisipasi dari semua komponen yang bergerak di dalam kegiatan pendidikan (Tilaar, 2004).

Pidarta dalam Mulyasa (2002) mengemukakan tiga macam keterampilan yang harus dimiliki oleh kepala sekolah untuk menyukseskan kepemimpinannya. Ketiga keterampilan tersebut adalah keterampilan konsep, yaitu keterampilan untuk memahami dan mengoperasikan organisasi; keterampilan manusiawi, yaitu keterampilan untuk bekerja sama, memotivasi dan memimpin; serta keterampilan teknik ialah keterampilan dalam menggunakan pengetahuan, metode, teknik serta perlengkapan untuk menyelesaikan tugas tertentu. Lebih lanjut dikemukakan bahwa untuk memiliki kemampuan, terutama keterampilan konsep, para kepala sekolah diharapkan melakukan kegiatan-kegiatan berikut: (1) senantiasa belajar dari pekerjaan sehari-hari terutama dari cara kerja para guru dan pegawai sekolah lainnya; (2) melakukan observasi kegiatan manajemen secara terencana; (3) membaca berbagai hal yang 
berkaitan dengan kegiatan-kegiatan yang sedang dilaksanakan; (4) memanfaatkan hasil-hasil penelitian orang lain; (5) berpikir untuk masa yang akan datang, dan (6) merumuskan ide-ide yang dapat diuji cobakan. Selain itu kepala sekolah harus dapat menerapkan gaya kepemimpinan yang efektif sesuai dengan situasi dan kebutuhan serta motivasi para guru dan pekerja lain.

\section{Keterampilan Manajerial Kepala Madrasah dalam Meningkatkan Mutu Lulusan}

Manajer (Kepala Sekolah) dalam mencapai tujuan organisasi atau lembaga dituntut memiliki ketrampilan agar dapat menjalankan fungsi manajemen yang diperlukan. Kepala sekolah harus menyediakan pendidikan yang lebih baik dan memadai kepada siswa. Untuk dapat mengkoordinasikan, menggerakkan dan menyerasikan semua sumber daya pendidikan diperlukan kepala sekolah yang memiliki kemampuan manajerial yang tangguh. Dengan ditunjang adanya kejelasan koridor kebijakan, kesamaan persepsi dan deregulasi akan lebih mengembangkan organisasi pendidikannya. Faktor lain yang juga diperhatikan adalah mengoptimalkan peran serta masyarakat dan kontrol (pengawasan masyarakat). Peran serta masyarakat dalam bidang pendidikan sangat strategis karena merupakan lingkungan yang pertama dan utama bagi sekolah.

Menurut Kast terdapat tiga bidang keterampilan manajer yang diperlukan oleh manajer pendidikan yaitu, keterampilan konseptual, keterampilan hubungan dengan manusia dan keterampilan teknik. Keterampilan-keterampilan manajer diperlukan untuk melaksanakan tugas secara efektif, akan tetapi jenis keterampilan berbeda hal mana tergantung dalam tingkat manajer yang bersangkutan dalam organisasi (Winardi; 1990). Menurut Hersey (1995) mengklasifikasikan tiga jenjang manajer yakni : Top Manager, Middle manager, dan Supervisory Manajer, yang masing-masing jenjang memerlukan tiga keterampilan tersebut. Untuk Top Manager keterampilan yang dominan adalah konseptual, Middle Manager adalah keterampilan hubungan manusia dan Supervisory Manager peran yang paling besar keterampilan teknik.

Dengan demikian, keterampilan manajerial adalah kemampuan untuk melaksanakan tugas berdasarkan kompetensi yang dilakukan oleh seseorang dalam mencapai tujuan, bekerjasama dengan orang lain. Dalam bidang pendidikan, keterampilan kepala sekolah sebagai manajer adalah kemampuan kepala sekolah dalam melaksanakan tugas berdasarkan kompentensi pekerjaan untuk mencapai tujuan melalui orang lain. Sedangkan kepala sekolah yang kompeten berarti menguasai kecakapan kerja atau keahlian yang sesuai dengan bidang kerja yang bersangkutan dan secara nyata kepala sekolah yang kompeten mampu bekerja dibidangnya secara efektif dan efisien 


\section{Keterampilan Konsep}

Pemahaman tentang pentingnya peranan manajer dalam mengemudikan organisasi ialah dengan mengetahui sifat pengetahuan yang dituntut. Secara umum dapat dikatakan bahwa semakin tinggi kedudukan seseorang dalam organisasi, pengetahuan yang dituntut dari padanya adalah pengetahuan yang memungkinkan berfikir secara generalis Siagian (1992). Lebih lanjut Siagian menjelaskan bahwa semakin rendah kedudukan seseorang, pengetahuan yang diharapkan diterapkannya semakin bersifat spesifik dan teknis, karena lebih menjurus kepada pelaksanaan berbagai kegiatan operasional.

Menurut Pidarta (1988) menyebutkan keterampilan konsep adalah keterampilan untuk memahami dan mengoperasikan organisasi. Sedangkan menurut Winardi (1990), keterampilan konsep merupakan kemampuan untuk memahami dan merangkum semua aktifitas dan kepentingan-kepentingan organisasi yang bersangkutan. Lebih lanjut Pidarta (1988) menyebutkan yang dipandang sebagai keterampilan konsep adalah menentukan strategi, kebijakan, mengkreasikan atau merencanakan sesuatu yang baru dan memutuskan. Keterampilan konsep adalah kemampuan mental untuk mengkoordinasi, memecahkan masalah, membuat keputusan dan pembuatan rencana.

Berdasarkan pendapat tersebut di atas dapat ditarik kesimpulan bahwa keterampilan konsep adalah kemampuan seorang manajer untuk melihat dan memahami organisasi sebagai suatu aktifitas dari unsur-unsur yang saling terkait untuk mencapai tujuan. Sedangkan keterampilan yang berkaitan dengan keterampilan konsep meliputi kegiatan perencanaan, strategi, kebijakan dan pengambilan keputusan.

\section{a. Perencanaan}

Perencanaan merupakan kegiatan pertama dalam proses manajemen. Apa yang akan dilaksanakan dalam rangka mencapai tujuan yang diharapkan perlu dipersiapkan dan dipikirkan secara intensif. Suatu usaha tanpa rencana, sukar diharapkan daya guna dan hasil gunanya. Coomd dalam Effendi (1997) mengemukakan bahwa perencanaan pendidikan adalah aplikasi rasional dan analisis terhadap perkembangan pendidikan dengan tujuan menjadikan pendidikan lebih efektif dan efisien dalam merespon kebutuhan-kebutuhan dan tujuan-tujuan siswa dan masyarakat akan pendidikan. Sedangkan menurut Gaffar (1987) perencanaan dapat diartikan sebagai proses penyusunan berbagai keputusan yang akan dilaksanakan pada masa yang akan datang untuk mencapai tujuan yang ditentukan. 
Dari definisi di atas dapat dikemukakan bahwa perencanaan pendidikan merupakan suatu proses rasional dan analisis pendidikan untuk menetapkan kebijakan langkah dan kegiatan di masa depan dalam rangka mencapai tujuan secara efektif dan efisien. Apabila dirumuskan secara operasional bahwa perencanaan adalah kegiatan yang dilakukan oleh kepala sekolah dengan tim dalam menyusun program-program, kegiatan sekolah yang akan dilaksanakan untuk mencapai tujuan pendidikan di sekolah secara efektif dan efisien.

Bentuk perencanaan yang sesuai karakteristik otonomi sekolah adalah perencanaan partisipatif, yaitu perencanaan yang melibatkan beberapa orang yang berkepentingan dalam kegiatan. Lebih lanjut dijelaskan bahwa perencanaan partisipatif melibatkan semua personalia lembaga pendidikan dan masyarakat melalui wakil-wakilnya, dan kegiatan penentuan kebutuhan sampai dengan perencanaan itu berhasil (Pidarta, 1990). Dengan demikian perencanaan partisipatif adalah perencanaan yang melibatkan guru, karyawan, siswa, orang tua siswa, tokoh masyarakat dan kepala sekolah yang bertindak sebagai koordinator.

Sekolah sebagai lembaga pendidikan harus memiliki rencana jangka panjang dalam bentuk rencana strategi, yaitu suatu proses kegiatan berkesinambungan dengan mempertimbangkan kondisi internal sekolah serta mengintegrasikan kondisi eksternal.

Menurut Fattah (1996) di dalam menyusun rencana strategi, sekolah harus mempertimbangkan beberapa aspek, yaitu:

1) Analisis lingkungan internal untuk mengukur kekuatan dan kelemahan organisasi.

2) Analisis lingkungan eksternal untuk melihat peluang dan tantangan yang dihadapi.

3) Penentuan tujuan dan sasaran yang ingin dicapai pada masa mendatang.

4) Strategi pencapaian tujuan berdasarkan alternatif yang dirumuskan.

5) Penerapan atau implementasi pencapaian tujuan dan strategi untuk mencapai tujuan.

Di samping rencana strategi, sekolah harus memiliki perencanaan operasional. Strategi pencapaian tujuan sekolah, dilaksanakan dengan melaksanakan kegiatan melalui kegiatan operasional. Perencanaan operasional memusatkan perhatian pada apa yang akan dikerjakan pada tingkat pelaksanaan dari suatu rencana strategi. Perencanaan ini bersifat spesifik dan 
berfungsi untuk memberikan petunjuk kongkrit tentang bagaimana suatu program dilaksanakan menurut aturan, prosedur yang telah ditetapkan secara jelas

Menurut Pidarta (1990) langkah-langkah proses perencanaan operasional melalui tahap-tahap yaitu:

1) Menspesifikasi tujuan.

2) Membentuk atau menentukan standar performan.

3) Menentukan alat / metode / alternatif pemecahan.

4) Melakukan implementasi dan menilai.

5) Mengadakan review.

\section{b. Penetapan Strategi}

Tugas seorang manajer dalam usaha memajukan dan melangsungkan organisasi adalah menetapkan strategi. Strategi ini termasuk jenis perencanaan, karena akan menentukan tindakan-tindakan pada masa datang untuk mencapai tujuan yang diinginkan.

Robbins (2001) membedakan dua macam strategi umum dan strategi khusus. Strategi umum bisa berupa salah satu dari upaya mempertahankan stabilitas, pengembangan, pemotongan atau pengurangan atau kombinasi dari ketiganya. Sedangkan strategi khusus ialah bergerak dalam segi layanan produksi, proses, pemasaran pemakaian lulusan dan keuangan.

Selanjutnya Pidarta (1988) menjelaskan strategi mempertahankan stabilitas digunakan akibat takut menerima resiko bila mengadakan perubahan, mereka sudah merasa puas dengan keadaannya saat ini. Strategi pengembangan dilaksanakan bila lembaga pendidikan ingin mendapatkan kemajuan dalam pendidikan yang dilaksanakan. Sementara itu strategi pemotongan dilakukan adalah karena lembaga merasa tidak mampu melaksanakan semua aktifitas pendidikan yang telah ada, maka satu atau beberapa diantaranya dihentikan. Sedangkan strategi kombinasi ialah melaksanakan dua atau tiga strategi itu sekaligus, tetapi setiap strategi dilaksanakan pada bagian tertentu dan lembaga itu sesuai dengan kebutuhan atau kondisinya.

Atas dasar uraian tersebut diatas dapat disimpulkan bahwa dalam rangka mencapai tujuan organisasi, manajer dengan menggunakan dan memanfaatkan fasilitas-fasilitas secara maksimal dapat menetapkan strategi. Penguasaan pengetahuan yang bersifat spesialistis akan kurang bermanfaat dalam memecahkan masalah-masalah yang strategis. Oleh karena itu 
semakin memahami hubungan dan interdependensi yang ada dan tidak memusatkan perhatian pada bagian-bagian tertentu saja dari organisasi.

Menurut Pidarta (1988), jenis strategi apapun yang akan diambil oleh manajer hendaklah memperhatikan hal-hal berikut sebagai bahan untuk memutuskannya., yaitu:

1) Informasi yang akan ditangani.

2) Pengalaman pribadi terutama bagi manajer yang sudah lama melaksanakan tugas. Pengalaman yang lampau yang sudah berhasil dapat dicoba kembali dan menghindari pengalaman pahit.

3) Pengalaman atau praktek-praktek yang berhasil dan pengalaman lembaga yang lain.

4) Seni dan intuisi pribadi. Konsep-konsep atau teori-teori tentang manajemen tidak selalu tepat diterapkan dalam praktek. Ia membutuhkan seni dan intuisi pemakai untuk pengelolaannya agar tepat dipakai dalam situasi dan kondisi tertentu.

5) Kondisi lembaga, yaitu banyaknya personalia serta tingkat kompetensinya masing-masing, jumlah sarana dan media pendidikan, tersedianya dana, besar kelas atau jumlah siswa.

6) Situasi lingkungan terutama lingkungan masyarakat.

7) Kecenderungan masa depan, termasuk harapan negara.

\section{c. Penetapan Kebijakan}

Di samping keterampilan menentukan strategi, seorang manajer harus mampu menetapkan kebijakan. Menurut Pidarta (1988) strategi berkaitan dengan kebijakan, sebab ada kalanya kebijakan tertentu memungkinkan mengambil strategi tertentu, atau suatu strategi dapat didukung pelaksanaannya oleh kebijakan tertentu. Menurut Sanusi (1989) menjelaskan kebijakan adalah serentetan tindakan atau tidak bertindak apa-apa terhadap suatu penyelesaian suatu tujuan yang dimaksudkan atau diharapkan. Sedangkan S.P. Hasibuan (1996) menjelaskan, kebijakan adalah suatu pedoman yang menyeluruh baik lisan maupun tulisan yang memberikan suatu batas umum dan arah tempat manajemen melakukan kegiatan.

Dari beberapa pendapat tersebut diatas dapat disimpulkan bahwa kebijakan menekankan kepada tindakan atau serentetan tindakan yang diambil dalam menyelesaikan suatu urusan atau masalah. Di samping itu, suatu kebijakan harus memenuhi unsurunsur tertentu yaitu pertama adanya orang atau orang-orang 
tertentu yang mempunyai kewajiban bertindak bila menghadapi suatu keadaan adalah kepala sekolah. Kedua; keadaan yang spesifik yang mungkin sering terjadi dan ketiga adanya suatu tujuan yang akan dicapai melalui tindakan tersebut sehingga dapatlah dikatakan bahwa tindakan itu dapat dipandang sebagai suatu kebijakan apabila tindakan itu terjadi secara berulang-ulang demi suatu tujuan tertentu.

Massie dalam Pidarta (1988) menyebutkan ciri-ciri kebijakan yang baik yaitu:

1) Kebijakan hendaknya berhubungan dengan tujuan tertentu (khususnya dengan kasus yang ditangani)

2) Dapat dipahami dalam bentuk lisan maupun tulisan.

3) Dijelaskan secara gamblang agar dapat dilaksanakan pada masa mendatang.

4) Menyesuaikan diri kepada perubahan asal stabilitas lembaga tidak terganggu.

5) Masuk akal dan dapat dilaksanakan.

6) Boleh diinterpretasikan oleh pihak yang mengendalikan.

Dalam kaitannya dengan penerapan otonomi, kepala sekolah memiliki peran sebagai manajer, maka ia memiliki otonomi untuk bertindak demi keberhasilan lembaganya. Artinya manajer tidak memiliki keraguan dan kecanggungan apakah dibenarkan atau disalahkan dalam mengambil suatu kebijakan sendiri. Adanya inovasi yang secara terus menerus dilaksanakan dalam mencapai tujuan maka akan banyak menimbulkan permasalahan baru yang harus dipecahkan dengan berbagai kebijakan.

\section{d. Membuat Keputusan}

Sebagai manajer kepala sekolah sering menghadapi banyak masalah yang harus dipecahkan. Salah satu tugas kepala sekolah selaku manajer adalah memecahkan masalah dan membuat keputusan. Keputusan pendidikan merupakan faktor esensial dalam kebijakan pendidikan, tetapi perlu dikemukakan bahwa membuat keputusan itu berbeda dengan hanya sekedar memutuskan. Yang dimaksud dengan membuat keputusan atau decision making ialah menetapkan atau menentukan pilihan berdasarkan bukti, informasi, kepercayaan yang masuk akal, lugas dan relevan dengan tujuan yang ditetapkan semula.

Menurut Siagian (1992) pengambilan keputusan pada hakekatnya adalah suatu pendekatan yang sistematis terhadap 
suatu masalah yang dihadapi, pengumpulan fakta dan data yang relevan dengan masalah yang dihadapi, analisis masalah dengan menggunakan fakta dan data, mencari alternatif sehingga dikemukakan alternatif yang paling rasional dan penilaian hasil yang dicapai sebagai akibat dari keputusan yang diambil.

Membuat keputusan menurut Effendi (1997) dapat dibuat secara individual bila kondisi untuk menyelesaikan masalahnya dapat dikuasai individu tersebut, tetapi dapat juga dilaksanakan secara kelompok. Selanjutnya Effendi menjelaskan keputusan yang dibuat kelompok itu pada dasarnya harus memenuhi hal-hal berikut; 1) terdapat keyakinan diantara anggota kelompok bahwa ada masalah yang harus diselesaikan bersama, 2) mempunyai nilai-nilai standard yang dapat dipakai acuan, 3) mempunyai tujuan yang cocok untuk semua anggota, 4) ada kesediaan untuk menerima konsensus kelompok, 5) dan jumlah tidak terlalu banyak.

Otonomi sebagai model manajemen yang memberikan kekuasaan lebih besar kepada sekolah dan mendorong sekolah untuk melakukan pengambilan keputusan secara kelompok atau partisipatif, untuk memenuhi kebutuhan sekolah dalam kerangka pendidikan nasional. Pengambilan keputusan partisipatif adalah suatu cara untuk mengambil keputusan melalui penciptaan lingkungan yang terbuka dan demokratis dari warga sekolah (guru, siswa, karyawan, orang tua siswa tokoh masyarakat) didorong untuk terlibat secara langsung dalam proses pengambilan keputusan yang dapat berkontribusi terhadap pencapaian tujuan sekolah. Hal ini dilandasi oleh keyakinan bahwa jika seseorang dilibatkan untuk berpartisipasi dalam pengambilan keputusan, maka yang bersangkutan akan mempunyai "rasa memiliki" terhadap keputusan tersebut, sehingga yang bersangkutan akan terlibat dalam bertanggung jawab dan berdedikasi sepenuhnya untuk mencapai tujuan sekolah.

Dalam pengambilan keputusan dilakukan dengan pendekatan bertahap, artinya sebelum keputusan diambil ada langkah-langkah yang ditempuh terlebih dahulu. Hoy dan Miskel (1978) menyebutkan langkah itu meliputi : 1) perhatian problem yang akan diputuskan; 2) jelaskan problem atas dasar informasi yang diterima dan IMS (Informasi Manajemen. Secara Sistem); 3) bentuk kriteria keputusan; 4) alokasikan bobot pada kriteria; 5) buat alternatif-alternatif penyelesaian atas dasar informasi dengan pertimbangan konsekuensinya masing-masing; 6) pilih alternatif 
yang terbaik dan 7) putuskan bentuk program yang kemudian dinilai serta dimonitor.

Dari uraian langkah pengambilan keputusan di atas dapat dikemukakan bahwa proses pengambilan keputusan itu tidak terjadi secara kebetulan dan asal jadi, tetapi melalui proses rasional. Oleh sebab itu pengambilan keputusan harus dilakukan dengan memperhatikan :

1) Proses pengambilan keputusan dilakukan dengan kesengajaan.

2) Pengambilan keputusan dengan menggunakan sistematik.

3) Pengambilan keputusan pada hakekatnya merupakan pemecahan masalah dengan sebaik-baiknya.

4) Pengambilan keputusan harus didasarkan atas fakta yang diolah.

5) Pengambilan keputusan yang baik adalah pemilihan alternatif setelah dianalisis dengan matang.

\section{Keterampilan Hubungan Manusia}

Menurut Kossen (1986) bahwa hubungan manusia dapat didefinisikan sebagai telaah perilaku manusia dan antar hubungannya dalam organisasi dengan tujuan menggabungkan kebutuhankebutuhan dan sasaran-sasaran pribadi dengan kebutuhan- kebutuhan dan sasaran-sasaran organisasi secara menyeluruh. Keterampilan hubungan manusia adalah kemampuan seseorang di dalam bekerja dengan dan melalui orang lain secara efektif dan untuk membina kerja sama. Keterampilan hubungan manusia diperlukan pada semua tingkatan manajer dalam organisasi. Menurut Sutisna (1993), dalam bidang pendidikan keterampilan hubungan manusia adalah kemampuan kepala sekolah untuk mendirikan sistem komunikasi dua arah yang terbuka dengan personil sekolah dan anggota masyarakat lainnya untuk menciptakan suasana kepercayaan terhadap sekolah dan meningkatnya unjuk kerja guru.

Dari pendapat tersebut dapat disimpulkan bahwa besar peranan hubungan manusia dalam kegiatan administrasi dan manajemen. Karena lebih berhubungan dengan segi manusia, di mana manusia dipandang sebagai unsur yang sangat vital yang tentunya tidak dapat diperlakukan sama dengan unsur lain seperti alat-alat dan sarana prasarana. Untuk merealisasi ketrampilan dalam hubungan manusia, dapat dilakukan dengan usaha-usaha konkrit yaitu:

a. Menanamkan dan memupuk sikap saling menghargai antar sesama anggota organisasi. 
b. Mengembangkan perasaan saling mempercayai dengan anggota yang dipimpin maupun antar anggota itu sendiri.

c. Membantu guru-guru meningkatkan perkembangan sikap profesionalnya ke arah yang lebih baik.

d. Memupuk rasa persaudaraan yang terjalin melalui kegiatankegiatan sekolah.

e. Menghilangkan rasa saling mencurigai terhadap anggota maupun antar sesama anggota organisasi.

Menurut Effendi (1997) kemampuan hubungan manusia meliputi:

a. Kemampuan untuk memahami perilaku manusia dan proses kerja sama.

b. Kemampuan untuk memahami isi hati sikap dan motif orang lain.

c. Kemampuan untuk berkomunikasi secara jelas dan efektif.

d. Kemampuan menciptakan kerjasama yang efektif, kooperatif, praktis dan diplomatis.

e. Kemampuan berperilaku yang dapat diterima.

Berdasarkan rumusan diatas dapatlah disusun rumusan baru tentang keterampilan kepala sekolah yang berkaitan dengan hubungan manusia, terutama adalah kemampuan :

a. Menjalin komunikasi dan kerjasama dengan guru.

b. Memberikan bimbingan dan motivasi.

c. Memberikan penghargaan kepada guru yang berprestasi.

d. Menjalin komunikasi dan kerjasama dengan komite sekolah, orang tua dan masyarakat dalam pengembangan sekolah.

Masing-masing keterampilan kepala sekolah yang berkaitan dengan hubungan manusia di atas di uraikan di bawah.

a. Menjalin Komunikasi dan Kerjasama dengan Guru.

Dalam pelaksanaan otonomi sekolah, pengembangan komunikasi antar personil yang sehat perlu dikembangkan, baik oleh kepala sekolah maupun oleh para guru dan staf lainnya. komunikasi intern yang terbina dengan baik dan memberikan kemudahan dan keringanan dalam melaksanakan serta memecahkan pekerjaan sekolah yang menjadi tugas bersama.

Dalam suatu sekolah yang hubungan personilnya kurang harmonis, acuh tak acuh satu sama lain, sukar mencari titik temu dan jalan keluar dalam berbagai masalah pendidikan karena setiap personil menghadapi masalah pekerjaannya masing- 
masing dan mencari alternatif pemecahan masalah tersebut sendiri. Karena itu, kepala sekolah mempunyai kewajiban untuk membina komunikasi intern dengan sebaik-baiknya agar guru maupun staf lainnya mau dan mampu bekerjasama untuk meningkatkan kemampuan kinerjanya.

Upaya membina komunikasi tidak sekedar untuk menciptakan kondisi yang menarik dan hangat, tapi tetapi akan mendapatkan makna yang mendalam dan berarti bagi pendidikan dalam suatu sekolah. Dengan demikian, setiap personil dapat bekerja dengan tenang dan menyenangkan serta terdorong untuk berprestasi lebih baik dan mengerjakan tugas pendidikannya dengan penuh kesadaran.

Dalam menjalin komunikasi dan kerja sama dengan para guru dan staf lain sebaiknya kepala sekolah memiliki prinsip demokratis dan harus menganggap guru-guru itu bukan saja sebagai stafnya, tetapi juga partner (mitra) dalam kelompok. Menurut Mulyasa (2002), prinsip- prinsip yang perlu dimiliki kepala sekolah yaitu :

1. Bersikap terbuka, tidak memaksakan kehendak, tetapi bertindak sebagai fasilisator yang mendorong suasana demokratis dan kekeluargaan.

2. Mendorong para guru untuk mau dan mampu mengemukakan pendapatnya dalam memecahkan suatu masalah serta harus dapat mendorong aktivitas dan kreativitas guru.

3. Mengembangkan kebiasaan untuk berdiskusi secara terbuka dan mendidik guru-guru untuk mau mendengarkan pendapat orang lain secara obyektif.

4. Mendorong para guru dan pengawai lainnya untuk mengambil keputusan yang paling baik dan mentaati keputusan itu.

5. Berlaku sebagai pengarah, pengatur pembicaraan, perantara dan pengambilan kesimpulan secara redaksional.

\section{b. Pemberian Bimbingan dan Motivasi Kerja Kepada Guru.}

Keberhasilan suatu organisasi atau lembaga dipengaruhi oleh berbagai faktor, baik faktor yang datang dari dalam maupun yang datang dari lingkungan. Dari berbagai faktor tersebut motivasi merupakan suatu faktor yang cukup dominan dan dapat menggerakkan faktor-faktor lain ke arah keefektifan kerja.

Callahan and Clark (dalam Mulyasa, 2002) berpendapat bahwa motivasi merupakan tenaga pendorong atau penarik yang menyebabkan adanya tingkah laku ke arah tujuan tertentu. 
Sedangkan Maslow (1970) menjelaskan bahwa motivasi tenaga pendorong yang menyebabkan manusia berbuat sesuatu atau berusaha untuk memenuhi kebutuhannya.

Terdapat dua jenis motivasi, yaitu intrinsik dan ekstrinsik (Owen 1991). Motivasi intrinsik adalah motivasi yang datang dari dalam diri sendiri, misalnya pegawai melakukan suatu kegiatan karena ingin menguasai suatu keterampilan tertentu yang dipandang akan berguna dalam pekerjaannya. Sedangkan motivasi ekstrinsik adalah motivasi yang berasal dari lingkungan di luar diri seseorang, misalnya pegawai bekerja ingin mendapat pujian atau ingin mendapat hadiah dari pimpinan (Mulyasa, 2002).

Menurut Maslow (1943), hierarki kebutuhan sesungguhnya dapat digunakan mendeteksi motivasi manusia. Kebutuhan manusia dapat dibagi ke dalam lima kategori, yaitu :

1. Kebutuhan fisiologis, misalnya kebutuhan akan makanan, minuman, air dan udara.

2. Kebutuhan rasa aman, misalnya kebutuhan akan pakaian, tempat tinggal, dan perlindungan atas tindakan yang sewenang- wenang.

3. Kebutuhan kasih sayang, misalnya rasa disayangi, diterima dan dibutuhkan oleh orang lain.

4. Kebutuhan akan rasa harga diri, misalnya hasrat untuk memperoleh kekuatan pribadi dan penghargaan atas apa yang dilakukannya, dan

5. Kebutuhan akan aktualisasi diri, misalnya seseorang pemusik menciptakan komposisi musik atau seorang ilmuwan memenuhi suatu teori yang berguna bagi kehidupan.

Dalam hubungan dengan peningkatan kinerja pegawai, teori Maslow ini dapat digunakan sebagai pegangan untuk melihat dan mengerti mengapa pegawai (guru dan staf) yang sakit atau kondisi fisiknya tidak baik tidak memiliki motivasi untuk bekerja, pegawai lebih senang bekerja dalam suasana yang menyenangkan, pegawai yang merasa disenangi, di terima oleh teman dan pimpinannya memiliki minat untuk meningkatkan kinerjanya dibanding dengan pegawai yang diabaikan atau dikucilkan. Oleh karena itu, kepala sekolah selaku manajer pendidikan diharapkan mampu membimbing dan memberikan motivasi kepada guru dan staf lain sesuai kebutuhan.

\section{c. Pemberian Penghargaan Kepada Guru Berprestasi.}


Salah satu keterampilan hubungan manusia yang perlu dimiliki oleh kepala sekolah adalah pemberian penghargaan kepada guru yang berprestasi penghargaan sangat penting untuk meningkatkan kegiatan yang produktif dan mengurangi kegiatan yang kurang produktif (Mulyasa, 2002). Dengan penghargaan, guru akan terangsang untuk meningkatkan kinerja yang positif dan produktif. Penghargaan ini akan bermakna apabila dikaitkan dengan prestasi pegawai secara terbuka sehingga setiap guru memiliki peluang untuk meraihnya. Dalam memberi penghargaan ini kepala sekolah perlu melakukan secara tepat, efektif dan efisien agar tidak menimbulkan dampak negatif.

d. Menjalin Komunikasi dan Kerjasama dengan Komite Sekolah, Orang Tua dan Masyarakat.

Jalinan komunikasi antara sekolah dengan komite sekolah, orang tua dan masyarakat merupakan bentuk komunikasi ekstern (Mulyasa, 2002). Komite ini dilakukan dengan tujuan untuk mendapatkan masukan- masukan yang berkaitan dengan pelaksanaan kegiatan-kegiatan di sekolah. Oleh karena itu, kepala sekolah perlu melakukan hubungan/kerjasama dengan komite sekolah, orang tua dan masyarakat untuk mendukung pengembangan sekolah.

Hubungan antar sekolah dengan komite sekolah memiliki peran penting dan strategis dalam mengembangkan organisasi pendidikan, karena komite sekolah memiliki fungsi dan peranan yang sangat mendukung teracpainya program sekolah dan merupakan partner sekolah.

Di samping komite sekolah, kepala sekolah juga perlu melakukan hubungan dengan orang tua dan masyarakat untuk mencapai tujuan sekolah. Mulyasa (2002) mengatakan bahwa bentuk hubungan dengan orang tua dapat dijalin melalui berbagai cara, yaitu : melalui dewan sekolah, komite sekolah, pertemuan penyerahan buku rapor dan melalui ceramah ilmiah. Sedangkan bidang kerja sama antar sekolah dengan orang yang dapat dilakukan melalui proses pembelajaran, pengembangan bakat, dan pendidikan mental, serta bidang kebudayaan terutama dalam penggunaan bahasa Indonesia yang baik dan benar. Adapun kerja sama antara sekolah dengan masyarakat dapat dilakukan melalui bidang pendidikan kesenian, olah raga dan keterampilan, serta pendidikan bagi peserta didik yang berkelainan.

\section{Keterampilan Teknik}


Kepala Sekolah sebagai pemimpin puncak di sekolah, selain mempunyai kemampuan merencanakan, mengorganisasikan dan mengawasi program sekolah juga mampu berkomunikasi dengan personal serta mampu melaksanakan tugas-tugas yang bersifat teknis. Manajer membutuhkan keterampilan teknik yang cukup untuk melaksanakan suatu pekerjaan tertentu yang menjadi tanggung jawabnya, keterampilan teknik adalah kemampuan untuk menggunakan alat-alat, prosedur dan teknik suatu bidang khusus (Sutisna: 1993).

Dengan demikian keterampilan teknik yang dibutuhkan oleh kepala sekolah meliputi kemampuan untuk menggunakan alat-alat pengajaran, prosedur yang harus dilakukan untuk melaksanakan suatu proses pembelajaran. Pendapat yang sama dikemukakan oleh Terry (1987) bahwa keterampilan teknik meliputi keahlian dalam hal menggunakan suatu aktifitas spesifik yang meliputi suatu proses, prosedur dan teknik, keterampilan teknik memungkinkan orang yang bersangkutan melaksanakan mekanisme yang diperlukan untuk melakukan pekerjaan khusus.

Bentuk kegiatan kepala sekolah yang bersifat teknis menurut Sutisna (1993) adalah ; 1) Kepala sekolah melaksanakan supervisi kepada guru di kelas, 2) mengevaluasi dan merevisi program penganjaran guru, 3) membuat program pelaksanaan kegiatan pengajaran dengan menghubungkan kurikulum dengan waktu, fasilitas dan personal yang ada, 4) mengelola program evaluasi siswa, 5) mengkoordinasi penggunaan alat pengajaran, 6) membantu guru dalam perbaikan pengajaran, 7) membantu guru dalam mendiagnosis kesulitan belajar siswa, 8) mengatur dan mengawasi tata tertib siswa, 9) menyusun anggaran belanja sekolah, 10) menetapkan spesifikasi dan inventarisasi perlengkapan, 11) melaksanakan administrasi sekolah berupa laporan kegiatan sekolah, 12) mengatur fasilitas fisik sekolah meliputi operasionalisasi pemeliharaan gedung, halaman dan pengendalian keamanan.

Dari pendapat tersebut diatas dapat disimpulkan bahwa keterampilan teknik kepala sekolah sangat diperlukan erat kaitannya dengan aplikasi pengetahuan tentang cara pengelolaan kelas, penggunaan metode pembelajaran, teknik evaluasi, teknik pembuatan satuan pelajaran dan pengelolaan sarana prasarana serta mengarahkan dan membina guru beserta staf sekolah lainnya.

\section{Kesimpulan}

Terdapat tiga bidang keterampilan manajerial yang diperlukan oleh manajer pendidikan dalam mengembangkan organisasi pendidikan, yaitu keterampilan konsep, keterampilan hubungan dengan manusia dan 
keterampilan teknik. Keterampilan konsep merupakan kemampuan untuk memahami dan merangkum semua aktivitas, kepentingan organisasi yang bersangkutan. Keterampilan ini meliputi kegiatan (1) perencanaan, (2) penetapan strategi, (3) penetapan kebijakan dan (4) pengambilan keputusan. sedangkan keterampilan hubungan dengan manusia, meliputi kemampuan : (1) memahami perilaku manusia dan proses kerjasama, (2) melakukan komunikasi dan (3) menyejahterakan serta menangani konflik. Adapun keterampilan teknik, meliputi keahlian mempergunakan alat-alat, prosedur dan teknik suatu bidang khusus untuk melaksanakan proses pembelajaran.

\section{E. Daftar Pustaka}

Chung, K.H \& Megginson. L. 1981. Organizatial Behavior Developing Managerial Skill. New York: Harper \& Row.

Depdiknas. 2002. Pedoman Administrasi Sekolah Lanjutan Tingkat Pertama. Jakarta: Direktorat Pendidikan Lanjutan Pertama, Dirjen Dikdasmen.

Effendi, Onong U. 1997. Kepemimpinan dan Komunikasi. Bandung.

Fattah, N. 1996. Landasan Manajemen Pendidikan. Bandung: PT. Remaja Rosdakarya.

Gaffar, M.F. 1987. Perencanaan Pendidikan: Teori dan Metodologi. Jakarta: Proyek PLPTK Dirjen Dikti Depdikbud.

Hasibuan, Malayu. SP. 1996. Manajemen: Dasar, Pengertian, dan Masalah. Cetakan ke 10. Jakarta: PT. Toko Gunung Agung.

Hersey, P \& Blanchard, P. 1995. Management of Organizational Behavior Utilizing Human Resources. 9 th Edition. London: Prentice-Hall International Editions.

Hoy, W.K \& Miskel, C.G. 1978. Educational Administration Theory, Research and Practice. New York: Random House, Inc.

Kast, Fremont E. Organisasi dan Manajemen. Edisi ke 4, Jilid 1 dan 2. Jakarta: Penerbit Bumi Aksara.

Kossen, S. 1986. Aspek Manusia dalam Organisasi. Jakarta: Erlangga

Maslow, A.H. 1943. A Theory of Human Motivation, Psychological Review. Vol. 50.

Maslow, A.H. 1970. Motivation and Personality. New York: Addison-Wesley

Mulyasa, E. 2002. Manajemen Berbasis Sekolah. .

Ndraha, T. 1989. Budaya Organisasi. Jakarta: Penerbit Rineka Cipta

Owen, R.G. 1991. Organizational Behavior in Education. 4th Edition. Boston: Allyn and Bacon. 
Robbins. S.P. 1993. Organization Theory Structure, Design and Application. London: Prentice-Hall International, Inc.

Robbins. S.P. 2001. Organizational Behavior Concept Controversies and Application. London: Prentice-Hall International, Inc.

Sanusi, A. 1989. Kapita Selekta Pembahasan Masalah Sosial dan Pendidikan.Bandung: FPS IKIP Bandung.

Siagian, H. 1992. Administrasi Pendidikan Suatu Pendekatan Sistem. Semarang: Satya Wacana.

Sutisna, O. 1993. Administrasi Pendidikan Dasar Teoritis untuk Praktik Profesional. Bandung Angkasa.

Terry, G.R. 1987. The Principles of Management. Third Edition. Homewood Illinois: Richard Irwin.

Tilaar, H.A.R. 2004. Permasalahan Pendidikan Indonesia Perlu Dipetakan Kembali. Kompas: 12 Oktober 2004.

Winardi, 1990. Pengantar Tentang Teori Sistem dan Analisis Sistem. Bandung. Alumni. 